\title{
RELEVANSI DAN KEKUATAN HUKUM AKTA PERDAMAIAN DALAM PENYELESAIAN SENGKETA DI BIDANG EKONOMI
}

\section{The Relevance and the Force of Law to Settlement Agreement in Dispute Settlement in the Economy}

\author{
Rilda Murniati \\ Fakultas Hukum Universitas Lampung \\ email: rilda.murniatium@fh.unila.ac.id
}

\begin{abstract}
Business relationships can give rise to disagreements that need to be resolved through the procedures for handling civil cases. In practice to solve business problems, the parties can make a peace agreement in the form of a deed under hand or a notarial deed known as a deed of peace. Mediation is a part of the stage of completion of a court that is required is offered by the judges and may terminate the proceedings if it obtained an agreement in mediation by the litigants. However, to simplify the process of resolving civil cases the parties can make advance a peace agreement in the form of a deed under hand or a notarial deed. Furthermore, the deed of peace created in front of the notary, submitted to the court to obtain a determination of the judges to get legal certainty.
\end{abstract}

Keywords: The Power of Law, Deed of Peace, Dispute Resolution

\begin{abstract}
abstrak
Hubungan bisnis dapat menimbulkan perbedaan pendapat sehingga perlu diselesaikan melalui tata cara penanganan perkara perdata. Dalam praktik untuk menyelesaikan permasalahan bisnis para pihak dapat membuat kesepakatan perdamaian dalam bentuk akta di bawah tangan atau akta notaris yang dikenal dengan istilah akta perdamaian. Mediasi sendiri merupakan bagian dari tahap penyelesaian perkara di pengadilan yang wajib ditawarkan oleh majelis hakim dan dapat mengakhiri proses pengadilan tersebut jika diperoleh kata sepakat dalam mediasi oleh para pihak yang berperkara. Namun, untuk mempermudah proses penyelesaian perkara perdata maka para pihak dapat membuat terlebih dahulu kesepakatan perdamaian dalam bentuk akta di bawah tangan atau akta notaris. Selanjutnya akta perdamaian yang dibuat di depan notaris tersebut, diajukan ke pengadilan untuk memperoleh penetapan dari majelis hakim untuk mendapatkan kepastian hukum.
\end{abstract}

Kata Kunci: Kekuatan Hukum, Akta Perdamaian, Penyelesaian Sengketa 


\section{A. Pendahuluan}

Secara umum peraturan hukum perdata itu meliputi peraturan perundang-undangan dan perjanjian. Dalam suatu hubungan hukum, para pihak tidak menentukan khusus kewajiban dan hak dari hubungan hukum itu tetapi melaksanakan pengaturan kewajiban dan hak yang diatur dalam undang-undang. Untuk itu, kadang-kadang orang tidak mengetahui bahwa hubungan hukum atau pemenuhan hak dan kewajiban itu adalah pelaksanaan kewajiban dan hak yang timbul karena undang-undang. Berbeda jika dalam suatu hubungan hukum itu, kewajiban dan hak dari para pihak diatur dalam perjanjian yang disepakati. Mereka yang melakukan hubungan hukum tersebut dapat langsung mengetahui atau menuntut pemenuhannya jika kewajiban salah satu pihak tidak dipenuhi. Tidak dipenuhinya kewajiban dalam suatu hubungan hukum dapat mengakibatkan kerugian bagi pihak lain yang berhak. Jika kewajiban tidak dipenuhi oleh salah satu pihak maka mungkin pihak lain akan menuntut pemenuhan kewajiban atau dapat mempertahankan haknya dengan cara penyelesaian tertentu

Dalam hukum perdata dan hukum acara perdata telah diatur cara penyelesaian jika salah satu pihak tidak memenuhi kewajiban dalam suatu hubungan hukum. Cara penyelesaian yang diatur dalam hukum perdata meliputi penyelesaian oleh para pihak sendiri yang disebut dengan damai (perdamaian) atau cara penyelesaian melalui pengadilan. Dalam isi perjanjian yang dibuat para pihak sering ditentukan bahwa jika terjadi perselisihan dalam perjanjian ini maka para pihak akan menempuh cara damai terlebih dahulu yang dilakukan secara musyawarah untuk mufakat yang disebut dengan non litigasi. Jika perdamaian tidak tercapai maka para pihak akan menyelesaikan melalui pengadilan yang berwenang atau pengadilan negeri ditempat kedudukan hukum mereka (litigasi).

Hukum Perdata mengatur cara perdamaian baik non litigasi atau litigasi. Penyelesaian masalah pemenuhan kewajiban secara non litigasi dengan perdamaian telah diakui dan diatur sejak lama dalam KUHPerdata dalam Pasal 1851 KUHPerdata. Berdasarkan ketentuan Pasal 1851 KUHPerdata tersebut, suatu perdamaian itu harus dibuat tertulis. Dalam praktik pada masyarakat, bentuk tertulis itu dibuat dalam akta di bawah tangan atau akta otentik. Jika bentuk tertulis dari perdamaian itu dibuat di bawah tangan sering disebut dengan perjanjian perdamaian. Namun, jika dibuat berupa akta otentik maka disebut dengan akta perdamaian yang dapat dibuat oleh notaris atau lembaga pengadilan.

Saat ini, penyelesaian masalah perdata di luar pengadilan dengan perdamaian tidak hanya diatur dalam KUHPerdata, tetapi pembentuk Undang-Undang RI telah mengaturnya dalam Undang-Undang Nomor 30 Tahun 1999 tentang Arbitrase dan Alternatif Penyelesaian Sengketa (selanjutnya disingkat UU No.30 Tahun 1999). Dalam UU No. 30 Tahun 
1999 ditentukan tata cara penyelesaian sengketa melalui alternatif penyelesaian sengketa atau dalam istilah asingnya adalah Alternative Dispute Resolution (ADR) yaitu melalui prosedur yang disepakati para pihak dengan cara konsultasi, negosiasi, mediasi, konsiliasi atau penilaian ahli. UU No. 30 Tahun 1999 mengatur tentang cara penyelesaian sengketa bahwa putusan kesepakatan perdamaian para pihak yang bersengketa itu dibuat secara tertulis dan bersifat final dan mengikat bagi para pihak serta dilaksanakan dengan itikad baik. Bentuk tertulis dari kesepakatan perdamaian yang dibuat oleh para pihak untuk menyelesaikan sengketa yang timbul dari suatu hubungan hukum dalam penyelesaian sengketa perdata di bidang ekonomi dengan perdamaian adalah alternatif penyelesaian sengketa yang lebih cepat dan efektif yang dapat dilakukan di luar pengadilan dan di dalam pengadilan. Di luar pengadilan, berdasarkan KUHPerdata dan UU No. 30 Tahun 1999 tidak ditentukan arti dari bentuk tertulis tersebut. Dalam praktik para pihak dapat membuat kesepakatan perdamaian itu dalam bentuk akta di bawah tangan yang disebut perjanjian perdamaian atau akta notaris yang dikenal dengan istilah akta perdamaian. Pembuatan perjanjian perdamaian atau akta perdamaian berupa akta di bawah tangan atau akta notaris akan terkait dengan kekuatan pembuktian dari akta tersebut. Di dalam pengadilan, akta perdamaian adalah akta yang dibuat oleh majelis hakim berdasarkan kesepakatan yang diperoleh dari hasil mediasi. Dalam hukum acara perdata, mediasi merupakan bagian dari tahap penyelesaian perkara di pengadilan yang harus ditawarkan oleh majelis hakim dan dapat mengakhiri proses pengadilan tersebut jika diperoleh kata sepakat dalam mediasi oleh para pihak yang berperkara.

Dalam penyelesaian sengketa perdata termasuk di bidang ekonomi, notaris memiliki kewenangan untuk membuat akta mengenai suatu perkara perdata yang dapat digunakan sebagai bukti otentik kesepakatan para pihak untuk menyelesaikan suatu perkara. Selanjutnya kesepakatan yang dibuat di muka notaris tersebut digunakan sebagai dasar utama penyelesaian perkara jika perkara tersebut telah diajukan ke Pengadilan. Akta notaris tersebut kemudian dikuatkan.

Akta kesepakatan atau akta perdamaian yang dibuat para pihak di hadapan notaris dapat menjadi alternatif pilihan yang lebih efektif dan efisien untuk menyelesaikan sengketa yang timbul dari hubungan hukum perdata khususnya di bidang ekonomi. Efektif dan efisien untuk mengakhiri sengketa para pihak adalah terkait kekuatan pembuktian dari akta notaris tersebut. Akta notaris adalah salah satu bentuk dari akta otentik. Akta yang dibuat para pihak tentang hubungan hukum perdata atau penyelesaian perkara perdata yang dibuat dalam akta otentik di hadapan notaris adalah akta kesepakatan perdamaian yang terjadi di luar pengadilan. Dengan akta kesepakatan atau perdamaian tersebut, sengketa yang terjadi antara para 
pihak dinyatakan berakhir dan para pihak tidak akan melanjutkan sengketa itu ke pengadilan. Namun demikian, jika perkara tersebut diajukan ke pengadilan maka dapat pula para pihak tersebut menjadikan akta yang dibuat di muka notaris sebagai bukti otentik.

\section{B. Pembahasan}

\section{Penyelesaian Perkara Perdata yang Diputus dengan Akta Perdamaian di Pengadilan}

Penyelesaian atas perkara perdata termasuk sengketa di bidang ekonomi mengacu pada ketentuan sebagaimana diatur dalam hukum acara perdata? Dimulai dengan adanya gugatan ke pengadilan diikuti dengan proses penyelesaian perkara yang berakhir dengan akta perdamaian di muka pengadilan, terdiri dari tahapan-tahapan sebagai berikut:

\section{a. Pengajuan Surat Gugatan}

Apabila suatu perkara tidak dapat diselesaikan secara damai oleh pihak-pihak yang berperkara, jalan terakhir yang dapat ditempuh ialah memohon penyelesaian melalui pengadilan negeri. Adapun pihak yang mengajukan gugatan disebut penggugat (plaintiff), sedangkan pihak yang digugat disebut tergugat (defendant, opposant). Permohonan gugatan diajukan secara tertulis atau secara lisan jika penggugat tidak dapat menulis. Permohonan gugatan secara tertulis disebut surat gugatan. ${ }^{1}$ Menurut ketentuan hukum acara perdata, permohonan gugatan diajukan kepada ketua pengadilan negeri yang daerah hukumnya meliputi tempat tinggal tergugat. ${ }^{2}$

Surat gugatan yang dibuat oleh penggugat, pada hakikatnya harus memuat tiga hal, yaitu: ${ }^{3}$

1) keterangan lengkap mengenai pihak-pihak yang berperkara, meliputi nama, umur, alamat, pekerjaan, dan agama (identity of the parties);

2) dasar gugatan (fundamentum petendi) yang memuat uraian tentang kejadian atau peristiwa (factual grounds) dan uraian tentang hukum yaitu adanya hak dalam hubungan hukum yang menjadi dasar gugatan tersebut (legal grounds); dan

3) tuntutan yang dimohonkan penggugat agar diputuskan oleh pengadilan (petitum). Tuntutan dapat dirinci lagi menjadi dua macam,yaitu tuntutan primer (primary claim) yang merupakan tuntutan pokok dan tuntutan subsider (subsidiary claim) yang merupakan tuntutan pengganti jika tuntutan pokok tidak dipenuhi.

\footnotetext{
${ }^{1}$ Abdulkadir Muhammad, Hukum Acara Perdata Indonesia, (Bandung: Citra Aditya Bakti, 2008), hlm. 37.

${ }^{2}$ Ibid., hlm. 40.

${ }^{3}$ Ibid., hlm. 37.
} 


\section{b. Pemeriksaan Perkara di Pengadilan}

Hukum Acara Perdata mengatur penentuan waktu sidang dan pemanggilan pihak-pihak yang berperkara dalam Pasal 121 dan Pasal 122 HIR atau Pasal 145 dan Pasal 146 RBg. Setelah perkara perdata didaftarkan di kepaniteraan pengadilan negeri, ketua pengadilan negeri menetapkan majelis hakim yang akan memeriksa perkara perdata. ${ }^{4}$

Pemeriksaan perkara di muka sidang pengadilan dilakukan oleh satu tim hakim yang berbentuk majelis hakim yang terdiri dari tiga orang hakim, seorang bertindak sebagai hakim ketua majelis dan lainnya sebagai hakim anggota. Sidang majelis hakim yang memeriksa perkara dibantu oleh seorang panitera atau seorang yang ditugaskan melakukan pekerjaan panitera yang lazim disebut panitera pengganti. Panitera atau panitera pengganti bertugas mengikuti semua sidang dan musyawarah majelis hakim serta mencatat semua hal yang dibicarakan dalam sidang. ${ }^{5}$

Pada awal persidangan, sebagaimana ketentuan dalam hukum acara perdata maka setelah ketua majelis hakim menyatakan sidang dibuka dan terbuka untuk umum, majelis hakim segera mulai memeriksa pihak-pihak yang berperkara. Terlebih dahulu ketua majelis hakim menanyakan identitas pihak-pihak, misalnya nama, umur, pekerjaan, tempat tinggal, dst. Kemudian ketua menanyakan kepada tergugat apakah sudah mengerti mengapa dia dipanggil ke muka sidang, apakah sudah menerima turunan surat gugatan yang ditujukan kepadanya. Ketua membacakan isi surat gugatan penggugat terhadap tergugat dan seterusnya. Setelah itu, ketua menjelaskan kepada pihak-pihak tentang persoalan perkara mereka guna selanjutnya menawarkan perdamaian (reconciliation) kepada pihak-pihak yang berperkara. ${ }^{6}$

\section{c. Putusan Pengadilan Berdasarkan Akta Perdamaian}

Setiap perjanjian perdamaian harus mengakhiri perkara secara tuntas dan keseluruhan. Tidak boleh ada yang tertinggal. Perdamaian harus membawa para pihak terlepas dari seluruh sengketa. Tidak ada lagi yang disengketakan karena semuanya telah diatur dan dirumuskan penyelesaiannya dalam perjanjian. Selama masih ada yang belum diselesaikan dalam kesepakatan, putusan perdamaian yang dikukuhkan dalam bentuk penetapan akta perdamaian mengandung cacat formil karena bertentangan dengan persyaratan yang ditentukan dalam Pasal 1851 KUHPerdata. $^{7}$

\footnotetext{
${ }^{4}$ Abdulkadir Muhammad. Op. Cit., hlm. 85.

${ }^{5}$ Ibid., hlm. 88.

${ }^{6}$ Ibid., hlm. 89.

${ }^{7}$ M. Yahya Harahap, Op. Cit., hlm. 275.
} 
Apabila perdamaian di muka sidang pengadilan dapat dicapai, maka acara berakhir dan majelis hakim dibantu oleh panitera membuatkan akta perdamaian (certificate of reconciliation) antara pihak-pihak yang berperkara yang memuat isi perdamaian, dan majelis hakim memerintahkan para pihak agar mematuhi dan memenuhi isi perdamaian tersebut. Akta perdamaian memunyai kekuatan mengikat (binding force of excecution) dan dijalankan sama dengan putusan hakim (Pasal 130 Ayat (2) HIR atau Pasal 154 Ayat (2) RBg).

Perdamaian bukanlah putusan yang ditetapkan atas tangung jawab pengadilan, melainkan sebagai persetujuan antara kedua belah pihak atas tanggung jawab mereka sendiri. Karena perdamaian terjadi di muka sidang pengadilan, majelis hakim membuatkan akta perdamaian menurut kehendak pihak-pihak yang berperkara. Oleh karena kesepakatan itu merupakan produk persetujuan para pihak yang digariskan Pasal 1230 KUHPerdata maka terhadapnya berlaku ketentuan Pasal 1337 KUHPerdata yang melarang persetujuan mengandung kuasa yang haram, yaitu persetujuan tidak boleh melanggar atau bertentangan dengan undang-undang, kesusilaan yang baik dan ketertiban umum. ${ }^{8}$ Itulah sebabnya putusan akta perdamaian tidak dapat dimintakan banding (Pasal 130 Ayat (3) HIR atau Pasal 154 Ayat (3) RBg.). Untuk itu, Majelis Hakim menetapkan dan memberikan putusan yang berkepala "Demi Keadilan Berdasarkan Ketuhanan Yang Maha Esa" dan mengadili dengan menghukum para pihak untuk menepati/mentaati perdamaian yang telah disetujui tersebut.

Dengan penetapan putusan hakim berupa akta perdamaian yang telah dibacakan dalam sidang terbuka untuk umum, maka perselisihan atau persengketaan yang telah terjadi antara para pihak dinyatakan menjadi berakhir dengan putusan perdamaian dan untuk selanjutnya akta perdamaian menjadi putusan tersebut adalah mengikat dan harus dilaksanakan dengan itikad baik serta tidak dapat dimintakan banding.

\section{d. Pelaksanaan Putusan Perdamaian}

Dengan berakhirnya perkara ini melalui upaya perdamaian yang telah ditetapkan dalam akta perdamaian di muka pengadilan, maka setiap putusan perdamaian harus dipatuhi dan dilaksanakan sebagaimana yang ditetapkan dalam putusan perdamaian dalam perkara ini. Untuk itu, setiap putusan perdamaian memiliki kekuatan mengikat untuk dipatuhi dan dilaksanakan sebagaimana ditentukan dalam Pasal 1858 Ayat (1) KUHPerdata bahwa perdamaian di antara pihak sama kekuatannya seperti putusan hakim yang penghabisan. ${ }^{9}$ Hal ini ditegaskan pula pada kalimat terakhir pada Pasal 130

\footnotetext{
${ }^{8}$ M. Yahya Harahap, Op. Cit., hlm. 277.

${ }^{9}$ Ibid., hlm. 279.
} 
Ayat (2) HIR bahwa putusan akta perdamaian memiliki kekuatan sama seperti putusan yang telah berkekuatan hukum sebagai putusan hakim yang telah memperoleh kekuatan hukum tetap dan juga berkekuatan eksekutorial (executorial kracht). ${ }^{10}$

Dengan demikian, sesaat setelah putusan dijatuhkan, maka langsung melekat kekuatan eksekutorial pada putusan tersebut. Apabila salah satu pihak tidak mentaati atau melaksanakan pemenuhan yang ditentukan dalam perjanjian perdamaian tersebut secara sukarela, maka dapat dimintakan eksekusi kepada pengadilan negeri, atas permintaan itu ketua pengadilan negeri menjalankan eksekusi sesuai dengan ketentuan Pasal 195 HIR. ${ }^{11}$

\section{Peran Akta Perdamaian yang Dibuat di Muka Notaris dalam Penyelesaian Sengketa di Bidang Ekonomi}

Proses perdamaian yang dilakukan oleh para pihak di muka pengadilan dan di hadapan mediator yang ditunjuk oleh pengadilan berlangsung dengan mudah dan singkat. Hal ini terjadi karena adanya bukti otentik berupa akta pernyataan di muka notaris dari tergugat dengan adanya gugatan penggugat kepada pengadilan negeri.

Akta pernyataan yang dibuat oleh para pihak di muka notaris menjadi akta yang sangat menentukan bagi tercapainya perdamaian atas perkara ini dan sekaligus mengakhiri sengketa di bidang ekonomi yang terjadi antara para pihak. Untuk itu, akta notaris memiliki kekuatan hukum yang dapat mempercepat proses pembuktian adanya hubungan hukum antara para pihak yang berperkara dan memiliki kekekuatan pembuktian yang sempurna sebagaimana yang ditentukan dalam kekekuatan pembuktian akta otentik. Kekuatan pembuktian akta otentik termasuk akta notaris menjadi dasar hukum yang paling menentukan dan menjamin kepastian hukum atas setiap hubungan hukum perdata.

Kewenangan notaris dalam pembuatan akta termasuk dalam pembuatan perjanjian yang dilakukan oleh para pihak, kekuatan pembuktian dari akta yang dibuat di muka notaris dan peran akta notaris dalam proses penyelesaian sengketa, adalah sebagai berikut:

\section{a. Kewenangan Notaris dalam Pembuatan Akta Otentik}

Wewenang notaris, secara umum notaris berwenang membuat akta otentik mengenai semua perbuatan, perjanjian dan ketetapan yang diharuskan oleh peraturan perundang-undangan dan/atau dikehendaki oleh yang berkepentingan untuk dinyatakan dalam akta otentik, menjamin

${ }^{10}$ M. Yahya Harahap, Ruang Lingkup Permasalahan Eksekusi Bidang Perdata. (Jakarta: Gramedia, 1995), hlm. 279-280.

${ }^{11}$ M. Yahya Harahap, Op .Cit., hlm. 280. 
kepastian tanggal pembuatan akta, memberikan groose, salinan dan kutipan akta, semuanya itu sepanjang perbuatan akta itu tidak juga ditugaskan atau dikecualikan kepada pejabat lain atau orang lain atau orang lain yang ditetapkan oleh undang-undang. Wewenang notaris adalah sebagai berikut:

1) mengesahkan tanda tangan dan menetapkan kepastian tanggal surat di bawah tangan dengan mendaftar dalam buku khusus;

2) membukukan surat-surat di bawah tangan dengan mendaftarkan dalam buku khusus;

3) membuat kopi dari surat-surat asli di bawah tangan berupa salinan yang memuat uraian sebagaimana ditulis dan digambarkan dalam surat yang bersangkutan;

4) melakukan pengesahan kecocokan fotokopi dengan surat aslinya;

5) memberikan penyuluhan hukum sehubungan dengan pembuatan akta;

6) membuat akta yang berkaitan dengan pertanahan; dan

7) membuat akta risalah lelang.

Berdasarkan ketentuan Pasal 1868 KUHPerdata, yang disebut dengan akta otentik adalah suatu akta yang dibuat dalam bentuk yang ditentukan oleh undang-undang, dibuat oleh atau di hadapan pegawai-pegawai umum yang berkuasa untuk itu dan di tempat dimana akta itu dibuatnya. Berdasarkan pernyataan di atas, suatu akta dapat disebut sebagai akta otentik apabila memenuhi persyaratan sebagai berikut:

1) akta itu harus dibuat "oleh" atau "di hadapan" seorang pejabat umum;

2) akta itu harus dibuat dalam bentuk yang ditentukan oleh undang-undang; dan

3) pejabat umum yang "oleh" atau "di hadapan" siapa akta itu dibuat, harus memunyai wewenang untuk membuat akta itu.

Pasal 1868 KUHPerdata tersebut hanya menerangkan apa yang dinamakan "akta otentik" akan tetapi tidak menjelaskan siapa yang dimaksud dengan "pejabat umum" itu, juga tidak menjelaskan tempat di mana ia berwenang demikian, sampai di mana batas-batas wewenangnya dan bagaimana bentuk menurut hukum yang dimaksud. Berdasarkan ketentuan Pasal 38 UU No 30 Tahun 2004 diatur mengenai bentuk hukum dan fungsi akta notaris adalah bahwa setiap akta notaris terdiri atas:

1) awal akta atau kepala akta, memuat:

a) judul akta;

b) nomor akta;

c) jam, hari, tanggal, bulan, dan tahun; dan

d) nama lengkap dan tempat kedudukan notaris.

2) badan akta, memuat:

a) nama lengkap, tempat dan tanggal lahir, kewarganegaraan, pekerjaan, jabatan, kedudukan, tempat tinggal para penghadap dan/atau orang yang mereka wakili; 
b) keterangan mengenai kedudukan bertindak penghadap;

c) isi akta yang merupakan kehendak dan keinginan dari para pihak yang berkepentingan;

d) nama lengkap, tempat dan tanggal lahir, serta pekerjaan, jabatan, kedudukan dan tempat tinggal tiap-tiap saksi pengenal.

3) akhir atau penutup akta, memuat:

a) uraian tentang pembacaan akta sebagaimana dimaksud dalam Pasal 16 Ayat (1) huruf I atau Pasal 16 Ayat (7);

b) uraian tentang penandatanganan dan tempat penandatanganan atau penerjemahan akta apabila ada;

c) nama lengkap, tempat dan tanggal lahir, pekerjaan, jabatan, kedudukan, dan tempat tinggal tiap-tiap saksi akta;

d) uraian tentang tidak adanya perubahan yang terjadi dalam pembuatan akta atau uraian tentang adanya perubahan yang dapat berupa penambahan, pencoretan atau penggantian.

Ketentuan dalam Pasal 38 UU Nomor 30 Tahun 2004 merupakan syarat-syarat yang harus dipenuhi sebagai akta notaris. Apabila dihubungkan dengan ketentuan Pasal 1868 KUHPerdata, maka Pasal 38 UU No. 30 Tahun 2004 tidak memuat saksi yang tegas terhadap notaris yang memuat akta yang tidak sesuai seperti yang diatur dalam Pasal 38 tersebut. Untuk itu, berlaku ketentuan Pasal 1868 KUHPerdata artinya bahwa akta tersebut tidak memenuhi syarat sebagai akta otentik karena bentuknya tidak sesuai yang ditentukan oleh undang-undang atau dapat dinyatakan cacat dalam bentuknya sehingga hanya memunyai kekuatan pembuktian sebagai akta di bawah tangan jika ditandatangani oleh para pihak. ${ }^{12}$

Akta otentik merupakan suatu alat bukti yang cukup, dan bila sudah ada akta otentik maka tidak perlu ditambahkan pembuktian lagi. Bukti yang cukup ini disebut juga pembuktian sempurna, ini berarti bahwa segala yang menjadi isi akta tersebut harus dianggap benar, kecuali apabila diajukan bukti perlawanan yang mengikat. Sebagaimana fungsi akta pada umumnya, maka akta notaris memiliki dua fungsi yaitu: ${ }^{13}$

1) Fungsi Formil (Formalitas Causa)

Fungsi formil suatu akta berarti bahwa untuk lengkap atau sempurnanya (bukan untuk sahnya) suatu perbuatan hukum, maka harus dibuatkan suatu akta atas perbuatan hukum tersebut. Para pihak yang melakukan suatu perbuatan hukum harus membuatnya dalam bentuk tertulis, baik akta otentik maupun akta di bawah tangan.

2) Fungsi Alat Bukti (Probationis Caus)

${ }^{12}$ Sjaifurrachman dan Habib Adjie, Aspek Pertanggungjawaban Notaris dalam Pembuatan Akta. (Bandung: Mandar Maju, 2011), hlm. 112.

${ }^{13}$ Sudikno, Mertokusumo, Hukum Acara Perdata Indonesia.(Yogyakarta: Liberty, 1982), hlm. 122. 
Sejak semula para pihak dengan sengaja membuat akta (otentik ataupun di bawah tangan) untuk suatu pembuktian di kemudian hari. Sifat tertulis suatu perjanjian tidaklah membuat sahnya suatu perjanjian, akan tetapi agar akta yang dibuat dapat dipergunakan sebagai alat bukti apabila timbul perselisihan di kemudian hari.

Berdasarkan pendapat di atas tentang fungsi akta otentik, maka dapat dinyatakan bahwa akta otentik sekurang-kurangnya memunyai tiga fungsi yaitu: ${ }^{14}$

1) sebagai bukti bahwa para pihak yang bersangkutan telah mengadakan perjanjian tertentu;

2) sebagai bukti bagi para pihak bahwa apa yang tertulis dalam perjanjian adalah menjadi tujuan dan keinginan para pihak; dan

3) sebagai bukti kepada pihak ketiga bahwa pada tanggal tertentu kecuali apabila ditentukan sebaliknya para pihak telah mengadakan perjanjian dan bahwa isi perjanjian adalah telah sesuai dengan kehendak para pihak.

\section{b. Kekuatan Pembuktian dari Akta yang Dibuat di Muka Notaris}

Sebagai suatu akta yang otentik maka akta notaris itu memiliki kekuatan pembuktian yang lengkap. Bukti lengkap ialah bukti yang sedemikian sehingga hakim memperoleh kepastian yang cukup (genoegzaam) untuk mengabulkan akibat hukum yang dituntut oleh penggugat, tanpa mengurangi kemungkinan ada bukti tentang kebalikannya. Untuk itu, akta notaris adalah akta otentik yang memiliki ketiga jenis pembuktian, yaitu: ${ }^{15}$

\section{1) Kekuatan Pembuktian Lahiriah (uitwendige bewijskracht)}

Kemampuan lahiriah akta otentik merupakan kemampuan akta itu sendiri untuk membuktikan keabsahannya sebagai akta otentik atau dalam bahasa latinnya adalah acta publica probant sesse ipsa artinya jika dilihat dari luar atau lahirnya sebagai akta otentik serta sesuai dengan aturan hukum yang sudah ditentukan mengenai syarat akta otentik maka akta tersebut berlaku sebagai akta otentik sampai terbukti sebaliknya artinya sampai ada yang membuktikan bahwa akta tersebut bukan akta otentik secara lahiriah. ${ }^{16}$ Dengan kekuatan pembuktian lahiriah ini dimaksudkan kemampuan dari akta itu sendiri untuk membuktikan dirinya sebagai akta otentik.

Kemampuan ini menurut Pasal 1875 KUHPerdata tidak dapat diberikan kepada akta yang dibuat di bawah tangan, akta yang dibuat di bawah tangan baru berlaku sah, yakni sebagai yang benar-benar berasal dari

\footnotetext{
${ }^{14}$ Sjaifurrachman dan Habib Adjie. Op. Cit., hlm. 115.

${ }^{15}$ GHS Lumban, Tobing, Peraturan Jabatan Notaris. (Jakarta: Erlangga, 1999), hlm. 55-59.

${ }^{16}$ Sudikno Mertokusumo, Op. Cit., hlm. 123.
} 
orang, terhadap siapa akta itu dipergunakan, apabila yang menandatanganinya mengakui kebenaran dari tanda tangannya itu. Apabila sesuatu akta kelihatannya sebagai akta otentik, artinya menandakan dirinya dari luar, dari kata-katanya sebagai yang berasal dari pejabat umum, maka akta itu terhadap setiap orang dianggap sebagai akta otentik, sampai dapat dibuktikan bahwa akta itu bukan akta otentik.

Sepanjang mengenai kekuatan pembuktian lahiriah ini, yang merupakan pembuktian lengkap dengan tidak mengurangi pembuktian sebaliknya maka akta partij dan akta pejabat dalam hal ini adalah sama. Suatu akta yang dari luar kelihatannya sebagai akta otentik, berlaku sebagai akta otentik terhadap setiap orang, tanda tangan dari pejabat yang bersangkutan (notaris) diterima sebagai sah. Kekuatan pembuktian lahiriah ini tidak ada pada akta di bawah tangan. Nilai pembuktian akta notaris dari aspek lahiriah, akta tersebut harus dilihat apa adanya, secara lahiriah tidak perlu dipertentangkan dengan alat bukti yang lain, jika ada yang menilai suatu akta notaris tidak memenuhi syarat sebagai akta otentik, maka yang bersangkutan wajib membuktikan bahwa akta tersebut secara lahiriah bukan akta otentik. $^{17}$

\section{2) Kekuatan Pembuktian Formal (Formele bewijskracht )}

Akta notaris harus memberikan kepastian bahwa suatu kejadian dan fakta tersebut dalam akta betul-betul dilakukan oleh notaris atau diterangkan oleh pihak-pihak yang menghadap pada saat yang tercantum dalam kata sesuai dengan prosedur yang sudah ditentukan dalam pembuktian akta. Secara formal untuk membuktikan kebenaran dan kepastian tentang hari, tanggal, bulan, tahun, pukul atau waktu menghadap, dan identitas dari para pihak yang menghadap comparanten, paraf dan tanda tangan para pihak/penghadap, saksi serta notaris, demikian juga tempat di mana akta itu dibuat, serta membuktikan apa yang dilihat, disaksikan, didengar oleh notaris. $^{18}$ Untuk itu, jika terdapat pihak yang mempermasalahkan aspek formal dari akta tersebut maka pihak tersebut harus dapat membuktikan ketidakbenaran tersebut. Jika tidak mampu membuktikan ketidakbenaran tersebut, maka akta tersebut harus diterima oleh siapapun.

\section{3) Kekuatan Pembuktian Materil (Materiele bewijskracht)}

Sepanjang yang menyangkut dengan kekuatan pembuktian material dari suatu akta otentik, terdapat perbedaan antara keterangan dari notaris yang dicantumkan dalam akta itu dan keterangan dari para pihak yang

\footnotetext{
${ }^{17}$ Sjaifurrachman dan Habib Adjie, Op. Cit., hlm. 116.

${ }^{18}$ Ibid., hlm. 117.
} 
tercantum didalamnya. Tidak hanya kenyataan, bahwa adanya dinyatakan sesuatu yang dibuktikan oleh akta itu, akan tetapi juga isi dari akta itu dianggap dibuktikan sebagai yang benar terhadap setiap orang, yang menyuruh adakan/buatkan akta itu sebagai tanda bukti terhadap dirinya atau yang dinamakan "prevue preconstituee", akta itu memunyai kekuatan pembuktian material. Kekuatan pembuktian inilah yang dimaksud dalam Pasal-Pasal 1870, 1871 dan 1875 KUHPerdata antara pihak yang bersangkutan dan para ahli waris serta penerima hak mereka, akta itu memberikan pembuktian yang kengkap tentang kebenaran dari apa yang tercantum dalam akta itu, dengan pengecualian dari apa yang dicantumkan di dalamnya sebagai hanya suatu pemberitahuan belaka (blote mededeling) dan yang tidak memunyai hubungan langsung dengan yang menjadi pokok dalam akta itu.

Akta notaris sebagai akta otentik memiliki kekuatan bukti yang lengkap atau sempurna dan memiliki kekuatan mengikat, serta telah mencukupi batas minimal alat bukti yang sah tanpa lagi diperlukan alat bukti lain dalam suatu sengketa perdata. Menurut Pasal 1870 KUHPerdata bahwa suatu akta otentik memberikan di antara para pihak beserta ahli warisnya atau orang yang mendapatkan haknya dari mereka suatu bukti yang sempurna tentang apa yang dimuat di dalamnya. Akta otentik merupakan suatu bukti yang mengikat dalam arti bahwa apa yang ditulis dalam akta tersebut harus dipercaya oleh hakim, yaitu harus dianggap sebagai benar selama ketidakbenarannya tidak dibuktikan.

Akta notaris sebagai akta otentik memberikan suatu bukti yang sempurna dalam arti bahwa ia sudah tidak memerlukan suatu penambahan pembuktian. Akta otentik itu tidak hanya membuktikan bahwa para pihak sudah menerangkan apa yang ditulis disitu, tetapi juga bahwa apa yang diterangkan itu adalah benar. ${ }^{19}$ Notaris diberi wewenang untuk menuangkan semua perbuatan, perjanjian, dan penetapan yang dikehendaki oleh pihak atau pihak-pihak yang sengaja datang kehadapn notaris untuk mengkonstatir keterangan itu dalam suatu akta otentik, dan agar akta yang dibuatnya itu memiliki kekuatan bukti yang lengkap dan memiliki keabsahannya. ${ }^{20}$ Kekuatan bukti lengkap meliputi kekuatan bukti lahiriah (luar), kekuatan bukti formal dan kekuatan bukti material. ${ }^{21}$ Untuk itu, notaris wajib memenuhi semua ketentuan-ketentuan jabatan notaris dan peraturanperaturan lainnya karena notaris bukan juru tulis semata-mata. Dengan demikian, notaris wajib mengaji apakah yang diinginkan penghadap untuk dinyatakan dalam akta otentik, tidak bertentangan dengan Undang-Undang Jabatan Notaris dan aturan hukum yang berlaku bagi akta otentik.

\footnotetext{
${ }^{19}$ R. Subekti, Hukum Pembuktian, (Jakarta: Pradnya Paramita, 2008), hlm. 27.

${ }^{20}$ Sjaifurrachman dan Habib Adjie, Op. Cit., hlm. 121.

${ }^{21}$ Suhardjono. Sekilas Tinjauan Akta menurut Hukum. Varia Peradilan, Nomor 123. hlm. 135.
} 


\section{Penutup}

Tahapan penyelesaian perkara meliputi: pemeriksaan perkara yaitu penyampaian isi gugatan dalam sidang yang terbuka untuk umum, diikuti pula dengan penawaran oleh majelis hakim bagi para pihak untuk menempuh upaya hukum perdamaian. Selanjutnya, para pihak melakukan mediasi yang dipimpin oleh seorang mediator. Alasan hakim mengabulkan dan memutus perkara tersebut dengan perdamaian adalah karena adanya kesepakatan dari para pihak yang telah dituangkan dalam akta pernyataan atau perdamaian dimuka notaris dan para pihak sepakat untuk mengakhiri sengketa sebagaimana yang telah disepakati dalam proses mediasi. Hasil kesepakatan mediasi tersebut dituangkan dalam Akta Perdamaian di muka pengadilan. Selanjutnya dilakukan eksekusi dan diikuti dengan pelaksanaan sita eksekusi atas barang sebagaimana diatur dalam hukum acara perdata.

Peran dari akta pernyataan yang dibuat di muka notaris sebagai akta yang memuat pernyataan tergugat atas gugatan dari Penggugat untuk menyatakan perdamaian yang dibuat di hadapan notaris yang harus mengacu pada ketentuan tentang syarat-syarat akta notaris dan syarat-syarat suatu akta otentik sebagaimana ditentukan dalam KUHPerdata.Untuk itu, sebagai akta otentik berupa akta notaris maka yang merupakan alat bukti yang memiliki kekuatan bukti yang lengkap dan sempurna serta tidak terbantahkan bagi para pihak yang menjadi dasar kewajiban dan hak para pihak dalam hubungan hukum dalam Akta Perdamaian yang diputus majelis hakim yang memiliki kekuatan eksekutorial sebagai putusan akhir bersifat final dan mengikat untuk mengakhiri sengketa di bidang ekonomi.

\section{Daftar Pustaka}

Afandi, Ali, 2004, Hukum Waris, Hukum Keluarga, Hukum Pembuktian, Jakarta: Penerbit Rineka Cipta.

Andasasmita, Komar, 1994, Sepintas Informasi tentang Pendidikan dan Praktek Notariat di Indonesia, Bandung: Penerbit Ikatan Mahasiswa Notariat Fakultas Hukum Universitas Padjajaran.

Harahap, M. Yahya, 2009, Hukum Acara Perdata, Jakarta: Penerbit Sinar Grafika.

, 1995, Ruang Lingkup Permasalahan Eksekusi Bidang Perdata. Jakarta: Penerbit Gramedia.

Kie, Tang Thong, 1994, Studi Notariat Serba Serbi Praktek Notaris. Jakarta: Penerbit Ichtiar Van Hoeve

Mertokusomo, Sudikno, 1988, Hukum Acara Perdata Indonesia, Yogyakarta: Penerbit Liberty. 
---------, 1982, Hukum Acara Perdata Indonesia, Yogyakarta: Penerbit Liberty.

Muhammad, Abdulkadir, 2004, Hukum dan Penelitian Hukum, Bandung: Penerbit PT Citra Aditya Bakti.

--------, 2010, Hukum Perdata, Bandun:g Penerbit PT Citra Aditya Bakti.

-------, 2008, Hukum Acara Perdata Indonesia, Bandung: Penerbit PT Aditya Bakti. 